\title{
Quantification of Biomass and Carbon Storage of the Herbaceous Stratum Around Refugee Camps: Case Study of Minawao Site in Cameroon
}

\author{
Paul Kodji ${ }^{1}$, Tchobsala ${ }^{1,}{ }^{*}$, Ibrahima Adamou ${ }^{2}$ \\ ${ }^{1}$ Department of Biological Sciences, Faculty of Science, University of Maroua, Maroua, Cameroon \\ ${ }^{2}$ Department of Biological Sciences, Faculty of Science, University of Ngaoundere, Ngaoundere, Cameroon
}

Email address:

Tchobsala2002@yahoo.fr (Tchobsala)

*Corresponding author

To cite this article:

Paul Kodji, Tchobsala, Ibrahima Adamou. Quantification of Biomass and Carbon Storage of the Herbaceous Stratum Around Refugee Camps: Case Study of Minawao Site in Cameroon. American Journal of Environmental and Resource Economics.

Vol. 6, No. 2, 2021, pp. 40-45. doi: 10.11648/j.ajere.20210602.12

Received: May 10, 2021; Accepted: May 27, 2021; Published: June 4, 2021

\begin{abstract}
Degradation of the savannah region contributes indirectly to climatic changes. In order to come across the impacts of anthropogenic actions on the herbaceous stratum, a carbon stock estimation study was conducted in the Sahelian savannah of Cameroon. Herbaceous inventories were carried out in each plant formation and also in each transect demarcated from refugee sites. These inventories were carried out in a $10 \mathrm{~m} \times 10 \mathrm{~m}$ plot. 5 circles with a radius of one (01) meter were delimited with a (01) ribbon in this quadrat. After data analysis in a laboratory, the wooded savannah $(2.44 \pm 3.70 \mathrm{t} / \mathrm{ha})$ shows the greatest amount of herbaceous biomass followed by the forest gallery $(1.81 \pm 2.47 \mathrm{t} / \mathrm{ha})$. The presence of a large quantity of carbon influence the locality of Zamay $(0.54 \pm 0.10 \mathrm{tC} / \mathrm{ha})$, meanwhile the village of Minawao present a very small quantity $(0.23 \pm 0.11$ $\mathrm{tC} / \mathrm{ha}$ ), where the refugees are settled. The impacts of the refugees are greater on carbon sequestration than those of the local populations. This study contributes to the understanding of carbon sequestration on the savannah region. To strengthen the potential of the herbaceous plants in this ecosystem are needed to minimize its degradation so that it can be a sustainable source of carbon stored by herbaceous.
\end{abstract}

Keywords: Refugee, Biomass, Herbaceous Stratum, Sahelian Savannah, Cameroon

\section{Introduction}

Greenhouse Gas (GHG) emissions from human activities, such as industrialization, land use and excessive exploitation of natural resources are responsible for the global warming currently observed on Earth [1]. Climate change impacts on the environment in which humans live, affecting the livelihoods of many people and the incomes of countries [2]. Indeed, $\mathrm{CO}_{2}$ is a gas that allows the earth to benefit from a natural effect of greenhouse that is essential for the human life, since it keeps the earth's average temperature at $15^{\circ} \mathrm{C}$ instead of $-18^{\circ} \mathrm{C}$. Moreover, increase in concentration has a direct influence on the effectiveness of this greenhouse by inducing global warming and climate changes [3]. Although the negative impacts associated with $\mathrm{CO}_{2}$ emissions are clearly recognised and identified, it is highly to note that in the coming decades these emissions will continue and even intensify [4]. Globally, carbon balance of terrestrial ecosystems plays an essential role, absorbing nearly $30 \%$ of the total anthropogenic $\mathrm{CO}_{2}$ emitted [2]. Having become aware of this reality, the international community has placed climate changes at the heart of its concerns. With this in mind, the Parties Conference in the year 2015 (CoP21) to the United Nations Framework Convention on Climate Changes (UNFCCC) in Paris brought together 195 countries to decide on the eventual measures put in place to limit global warming [5]. An international climate agreement, applicable to all countries, was approved by all participants, setting the objective of limiting global warming to between $1.5^{\circ} \mathrm{C}$ and 
$2^{\circ} \mathrm{C}$ by 2100 [6]. To this end, the agreement, which is supposed to come into force in 2020, will have to address both mitigation (the reduction of greenhouse gas emissions) and the adaptation of societies to existing and future climate disturbances [7].

The herbaceous layer has an important role to play in the ecosystem. It plays a crucial carbon storage function. In savannah areas where trees are rare, herbaceous plants are involved in carbon sequestration. Phytomass of the herbaceous stratum varies according to ecological zones, plant groupings and topography [8, 9]. On Sahelian rangelands, the available forage for domestic livestock consists of herbaceous and woody vegetation that is accessible or made accessible to animals [10]. In the Sahelian zone, herbaceous vegetation is more influenced by pastures, which play an important role in livestock feeding and constitute to the totality of the feed resources of ruminants on livestock farms [11]. More than $90 \%$ of the energy consumed by cattle comes from pastures [12]. Livestock farming and rainfall, with a high variability in time and space, conditioned carbon productivity. The current and past climatic variations recorded in recent decades have led to a series of droughts with a decrease in the production of herbaceous plants $[13,14]$. Any change in the management of this fodder resource requires prior knowledge of fodder resources and their production levels may impact their capacity carbon [15-19]. The savannahs are real fodder resources and offer very significant economic potential for agriculture and livestock farming ([20]. However, their wealth and carbon production are not yet well evaluated. Uses of savannas for agricultural and pastoral activities raises the question of sustainable land management and the rational use of biodiversity. It is therefore essential to have an inventory of a country's natural resources in order to make rational use of its land [21]. However, population density influences the primary production of vegetation. [22] point out in the same vein that refugee camps, where many people settle, suffer considerable environmental degradation. This plant degradation has a negative effect on the carbon storage of herbaceous plants [23]. The objective of this study is to assess the biomass and carbon of herbaceous stratum under the influence of refugees and local populations in the Sahelian savannah of the Far North Region of Cameroon.

\section{Materials and Methods}

\subsection{Study Site Location}

The Far North region of Cameroon covers the area of about $34,263 \mathrm{~km}^{2}$ [24] (Wafo, 2008), or about 7.21 percent of the country surface area. It is bordered to the north by the Republic of Chad, to the west by Nigeria and to the south by the Northern Region. The study took place precisely in Mayo-Tsanaga, $70 \mathrm{~km}$ from the city of Maroua (capital of the Far North region) [25].

Since 2013, village of Minawao in this Division has been considered as a site for Boko haram refugees. This village is located between $10^{\circ} 21^{\prime}$ North, $13^{\circ} 32^{\prime}$ East. It is bordered by four main villages, namely: Zamay in the north, Gawar in the south, Sabongari in the east and Windé in the west $[25,26]$.

Agriculture is a main source of activities for the villagers. However, population growth is leading to a scarcity of arable land and overexploitation of the soil. In order to optimise food management, division of the camp into four sectors, corresponding to the interventions of the four partners, which has been set up [27]. The relative dry climate of the region causes significant problems of shortages of drinking water.

\subsection{Determination of the Phytomass of Herbaceous Plants}

Measurements were systematically carried out at the intersection of two diagonals of each $10 \mathrm{~m}$ x $10 \mathrm{~m}$ plot. To evaluate this phytomass, 5 circles with a radius of one (01) metre were measured using a (01) tape [28]. Which gives a total of 1500 circles. The fresh herbs were harvested and weighed on site using a Sartorius scale (ISO 9001 to 10-3) to determine the total wet masses of each fraction, just a small sample (wrist) was collected and weighed in an oven at the ENSAI laboratory at the University of Ngaoundéré within 48 hours to determine the total dry mass (TDS). The total dry mass (TDS) was calculated according to the formula:

$$
\mathrm{TDS}=100 \times \mathrm{TDS} /(100+\mathrm{Te})
$$

Where TDS is the total wet weight and Te is the water content. $\mathrm{Te}=((\mathrm{MH}-\mathrm{MS}) / \mathrm{MS}) \times 100$ where $\mathrm{MH}$ is the wet mass and MS is the dry mass of the sample. These measurements allowed us to quantify the phytomass of herbaceous plants in the Sudano-Sahelian savannah.

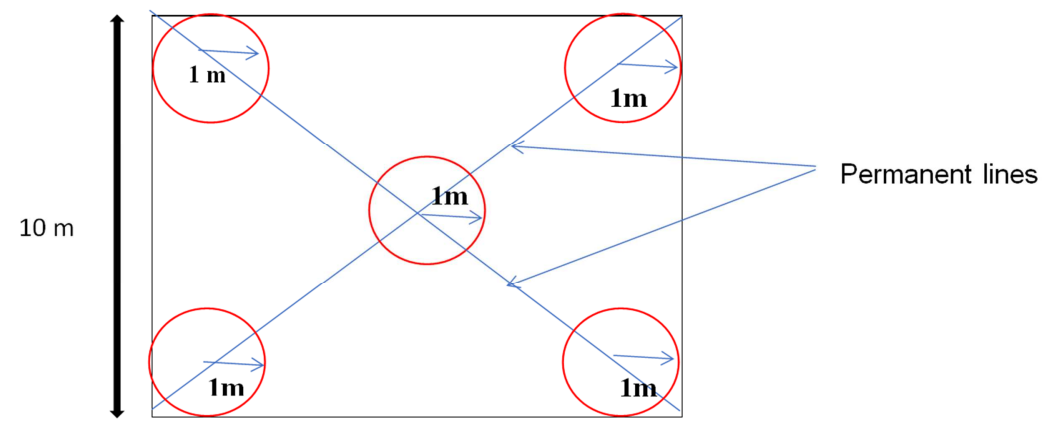

Figure 1. Method for quantifying carbon in herbaceous plants. 
In order to find out the impacts of the refugees on the herbaceous states as one moves away from the refugee site, a 15,000 $\mathrm{m} \times 20 \mathrm{~m}$ transect was delineated. Within each transect, the method in figure 1 was carried out randomly at each kilometers.

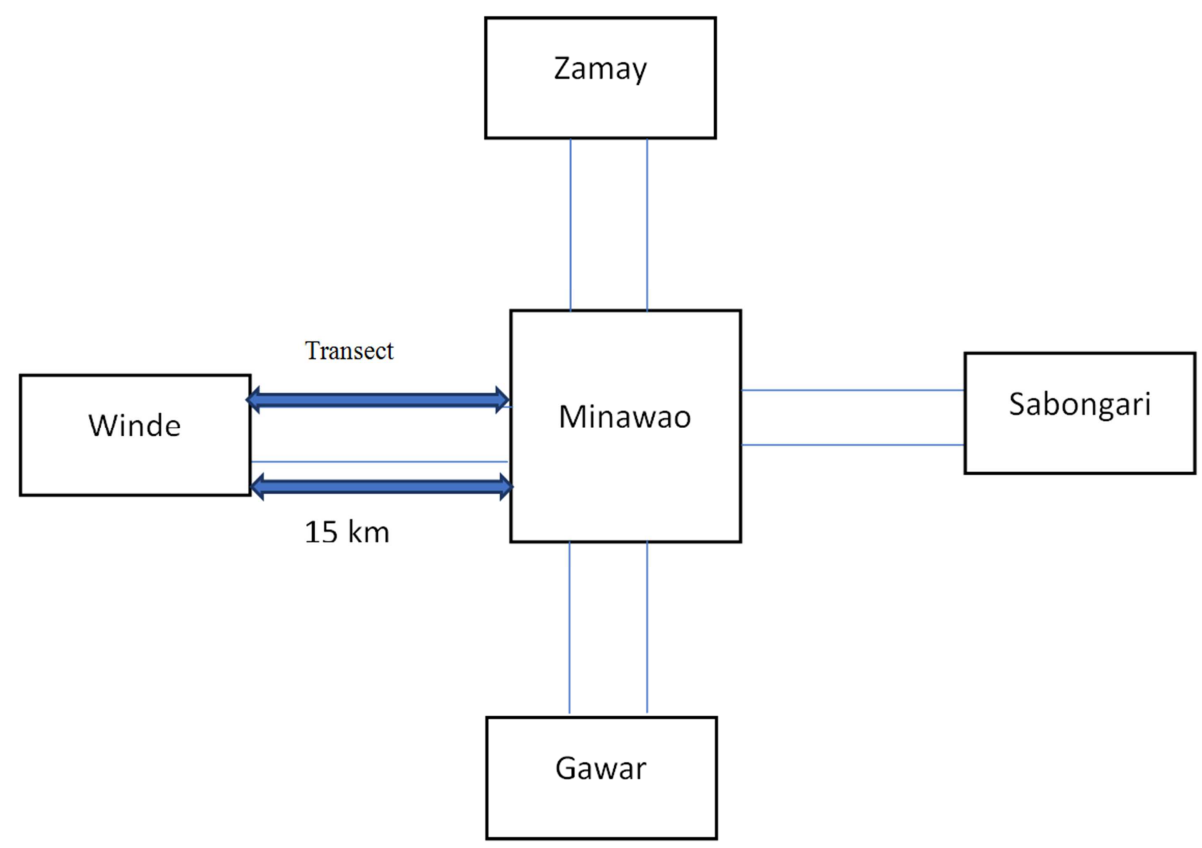

Figure 2. Method of quantifying carbon in herbaceous plants along the directions.

\section{Results and Discussion}

\subsection{Biomass of Herbaceous Plants According to Villages and Plant Formations}

The biomass of herbaceous plants in the different villages varies from one plant formation to another.

In the village of Gawar, the value of the herbaceous biomass varies from $0.54 \mathrm{t} / \mathrm{h}$ (dwellings) to $1.07 \mathrm{t} / \mathrm{ha}$ (forest gallery). In Minawao, this value is low and varies from 0.03 (fields) to $0.90 \mathrm{t} / \mathrm{ha}$ (wooded savannah). In Sabongari village, the value of the herbaceous biomass varies from $0.60 \mathrm{t} / \mathrm{ha}$ (fields) to $1.06 \mathrm{t} / \mathrm{ha}$ (forest gallery). In the village of Windé, the amount of herbaceous biomass varies between $0.82 \mathrm{t} / \mathrm{ha}$ (fields) and $1.14 \mathrm{t} / \mathrm{ha}$ (forest gallery). In Zamay, the highest biomass value of herbaceous plants was reported between
$0.78 \mathrm{t} / \mathrm{ha}$ (fields) and $1.37 \mathrm{t} / \mathrm{ha}$ (wooded savannah). The total biomass recorded in this zone according to villages and plant formations is $20.82 \mathrm{t} / \mathrm{ha}$. As far as villages are concerned, Zamay records the highest biomass value $(5.35 \mathrm{t} / \mathrm{ha})$ and in second position is Windé village $(4.87 \mathrm{t} / \mathrm{ha})$.

The wooded savannah shows the highest amount of herbaceous biomass $(5.15 \mathrm{t} / \mathrm{ha})$, followed by the forest gallery $(4.99 \mathrm{t} / \mathrm{ha})$. This result does not corroborate those of [29] who showed an almost nil contribution of herbaceous plants in the wooded savannah. Instead, these authors indicated a high herbaceous biomass in the shrubby savannah $(7.44 \mathrm{t} / \mathrm{ha})$. This difference would be due to the disparity of ecological zones. Analysis of variance indicates a significant difference between villages on the one hand and between plant formations on the other $(\mathrm{p}<0.0001)$.

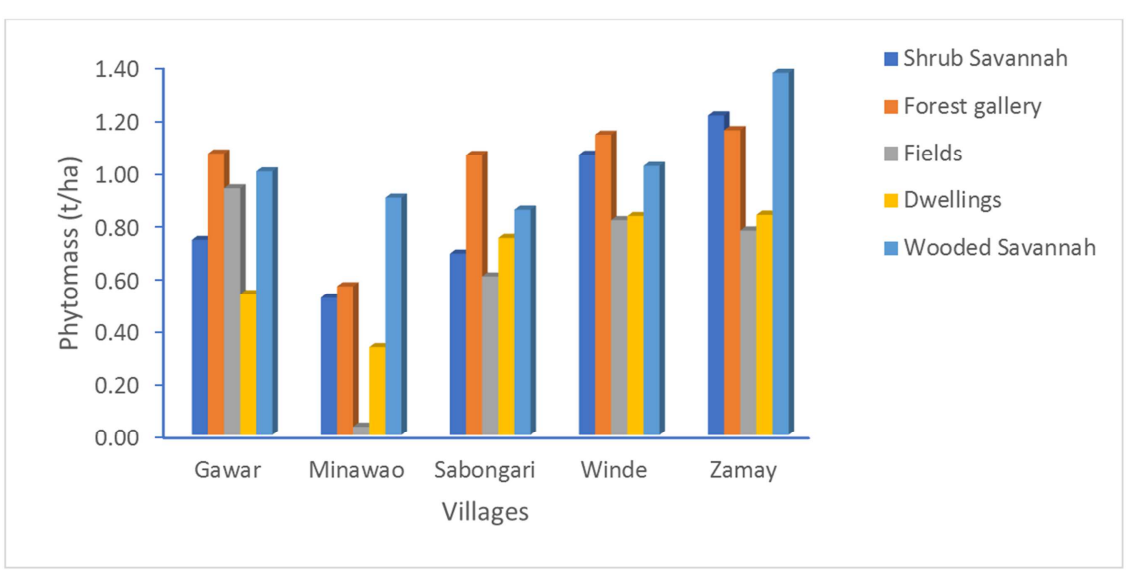

Figure 3. Biomass of herbaceous plants in the villages and plant formations. 


\subsection{Biomass of Herbaceous Plants as a Function of Distance and Direction}

The productivity of phytomass on herbaceous stratum according to distances and plant formations is shown in figure 4 . The results of this research show that phytomass production is varies from distance to distance and from direction to direction on the other hand $(\mathrm{p}<0.0001)$.

Biomass values vary from $3.23 \mathrm{t} / \mathrm{ha}(\mathrm{Mi}-\mathrm{Sa})$ to $7.57 \mathrm{t} / \mathrm{ha}$
(Mi-Za) depending on the direction. The direction of Minawao- Zamay is more productive with a maximum value of $1.9 \mathrm{t} / \mathrm{ha}$ at distance D3. Than Minawao- Sabongari which indicates a low production of herbaceous phytomass with a maximum value of $1.01 \mathrm{t} / \mathrm{ha}$. With regard to distances, biomass values vary from 2.91 (D1) to $5.64 \mathrm{t} / \mathrm{ha}$ (D3). The biomass of herbaceous plants varies according to plant diversity, therefore, depending on the specific contribution of the area [30].

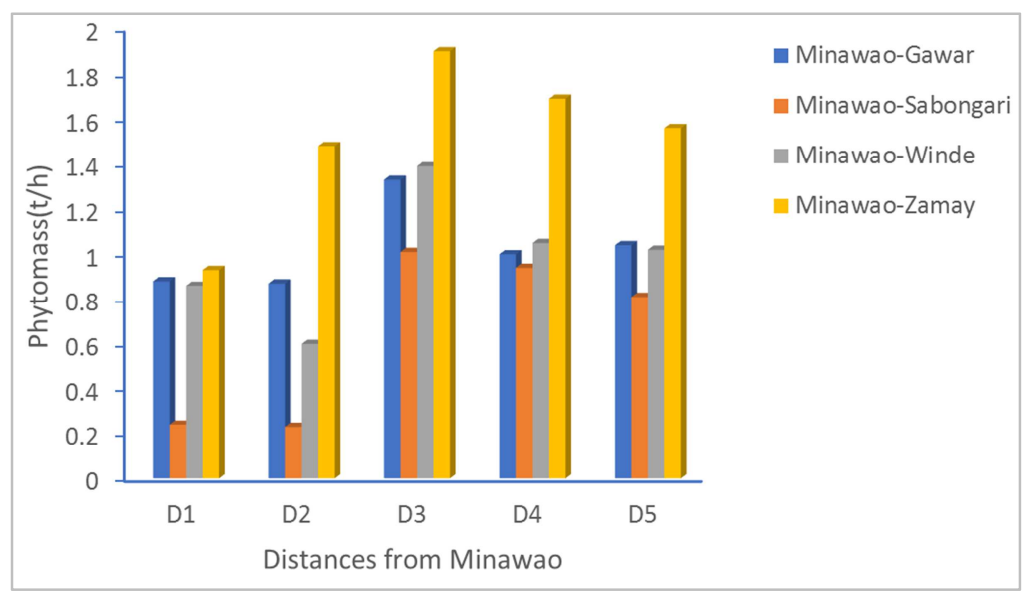

Figure 4. Herbaceous biomass as a function of distances and directions.

D1=Distance 3 kilometers from Minawao; D2=Distance 6 kilometers from Minawao; D3=Distance 9 kilometers from Minawao; D4=Distance 12 kilometers from Minawao; D5=Distance 15 kilometers from Minawao.

\subsection{Carbon Stock of Grass Species According to Villages and Plant Formations}

Estimating the amount of carbon in the phytomass of the grass stratum differs between villages and plant formations.

The villages of Zamay $(0.54 \pm 0.10 \mathrm{tC} / \mathrm{ha})$ and Windé $(0.48 \pm 0.06 \mathrm{tC} / \mathrm{ha})$ have a high carbon value. The villages of Minawao (0.23 $\pm 0.11 \mathrm{tC} / \mathrm{ha})$ and Sabongari $(0.39 \pm 0.06 \mathrm{tC} / \mathrm{ha})$, on the other hand, report a low carbon value for herbaceous plants. Herbaceous flora has a low contribution to the total carbon volume of the vegetation $([31,1]$. This low carbon value of herbaceous plants can attribute to the floristic composition in relation of soil conditions and to the structure of herbaceous groupings such as [32].

Depending on the plant formations, the carbon stock varies in decreasing order from $0.51 \pm 0.06 \mathrm{tC} / \mathrm{ha}$ in the wooded savannah, $0.49 \pm 0.08 \mathrm{tC} / \mathrm{ha}$ in the forest galleries, $0.42 \pm 0.11$ $\mathrm{tC} /$ ha in the shrubby savannah, $0.33 \pm 0.12 \mathrm{tC} / \mathrm{ha}$ in the fields and $0.32 \pm 0.08 \mathrm{tC} / \mathrm{ha}$ in the dwellings. The trees of savannah have the highest amount of carbon while the dwellings show a low value. This low carbon content of the gaseous stratum of the dwellings would be justified by anthropization pressure. Animals graze in the dwellings and anthropogenic activity is highly accentuated. Grazing and bush fires tend to reduce the amount of carbon in the grassy layer ([33, 34]. All the herbaceous strata on the different sites sequester $2.08 \pm 0.07$ $\mathrm{tC} / \mathrm{ha}$. This amount of carbon is less than the herbaceous carbon stock of $3.15 \mathrm{tC} / \mathrm{ha}$ recorded by [29] in the shrubby savannah zone of the Adamaoua region of Cameroon. This difference could be explained by ecological factors and the disparity of the study areas. On the other hand, the value found in the tree savannah $(0.51 \pm 0.06 \mathrm{tC} / \mathrm{ha})$ research is higher than the herbaceous carbon quantity of $0.16 \mathrm{tC} /$ ha observed by [29]. The density of woody trees, which is higher in wooded savannah (3967 individuals/ha) than in shrubby savannah (2933 individuals/ha) could be the factor in the latter difference. Herbaceous species develop better in the absence of large trees. In the Sudanian savannah, the production of herbaceous biomass is 3 times higher outside the woody canopy than under the canopy of tall trees [34]. However, climatic and ecological factors should not be neglected [35].

Table 1. Carbon of important grass species according to plant formations (tC/ha).

\begin{tabular}{lllllll}
\hline Plant formation & Gawar & Minawao & Sabongari & Windé & Zamay \\
\hline Shrub Savannah & 0.37 & 0.26 & 0.34 & 0.53 & 0.61 & 0.57 \\
Forest gallery & 0.53 & 0.28 & 0.53 & 0.53 & 0.41 & $0.49 \pm 0.08$ \\
Fields & 0.47 & 0.02 & 0.37 & 0.41 & $0.33 \pm 0.12$ \\
Dwellings & 0.27 & 0.16 & 0.43 & 0.51 & $0.32 \pm 0.08$ \\
Wooded Savannah & 0.5 & 0.45 & $0.39 \pm 0.06$ & $0.48 \pm 0.06$ & 0.69 \\
Average & $0.42 \pm 0.08$ & $0.23 \pm 0.11$ & $0.51 \pm 0.06$ & $2.08 \pm 0.07$ \\
\hline
\end{tabular}




\subsection{Carbon Stock of Important Grass Species as a Function of Distance and Direction}

Concerning distances, the carbon stock values of grass species vary between $0.36 \pm 0.12$ and $0.71 \pm 0.12 \mathrm{tC} / \mathrm{ha}$. The analysis of variance shows a significant difference between the distances $(\mathrm{p}<0.01)$.

Distance D3 $(0.71 \pm 0.12 \mathrm{tC} / \mathrm{ha})$ indicates the large amount of carbon. At this distance, anthropogenic activities and grazing are less intense, which leads to the normal development of some herbaceous plants. Research results on the carbon stock of savannah grasses in the intertropical zone show that carbon production is variable from one distance to another.

Depending on the direction, the carbon stock value varies from $0.34 \pm 0.17$ (Minawao-Sabongari) to $0.76 \pm 0.12 \mathrm{tC} / \mathrm{ha}$
(Minawao-Zamay). The analysis of variance shows a significant difference between the directions $(p<0.0001)$. In descending order, it is $0.76 \pm 0.12 \mathrm{tC} / \mathrm{ha}$ (Minawao-Zamay), $0.51 \pm 0.06 \mathrm{tC} / \mathrm{ha} \quad$ (Minawao-Gawar), $\quad 0.49 \pm 0.10 \mathrm{tC} / \mathrm{ha}$ (Minawao-Windé) and $0.34 \pm 0.17 \mathrm{tC} / \mathrm{ha}$ (Minawao-Sabongari).

The frequency of anthropogenic zoo activities would be less at the level of the distance D3 and the Minawao-Zamay direction, which explains the importance of the carbon stock at these levels. The exploitation of the reserve of Zamay's resources is principally limited, which would allow the herbaceous stratum to develop. Our results are significantly low than those of [29] in the Guinean high savannah of Adamaoua and [32] in Congo Brazzaville. The authors nevertheless indicated the same factors that may influence carbon sequestration in herbaceous strata as we did in this study.

Table 2. Herbaceous carbon stock by direction (tC/ha).

\begin{tabular}{lllllll}
\hline \multirow{2}{*}{ Directions } & Distances & & & & & D5 \\
\cline { 2 - 6 } & D1 & D2 & D3 & D4 & Derage \\
\hline Minawao-Gawar & 0.44 & 0.44 & 0.67 & 0.50 & 0.52 & $0.51 \pm 0.06$ \\
Minawao-Sabongari & 0.12 & 0.12 & 0.51 & 0.47 & 0.47 & $0.34 \pm 0.17$ \\
Minawao-Windé & 0.43 & 0.31 & 0.70 & 0.53 & 0.51 & $0.49 \pm 0.10$ \\
Minawao-Zamay & 0.47 & 0.74 & 0.96 & 0.85 & 0.78 & $0.76 \pm 0.12$ \\
Average & $0.36 \pm 0.12$ & $0.40 \pm 0.18$ & $0.71 \pm 0.12$ & $0.59 \pm 0.13$ & $0.57 \pm 0.10$ & $2.62 \pm 0.11$ \\
\hline
\end{tabular}

D1=Distance 3 kilometers from Minawao; D2=Distance 6 kilometers from Minawao; D3=Distance 9 kilometers from Minawao; D4=Distance 12 kilometers from Minawao; D5=Distance 15 kilometers from Minawao.

\section{Conclusion}

At the end of this study, the inventory of the herbaceous stratum made it possible to assess the biomass production and carbon stock of herbaceous plants under refugee pressure. The state of the herbaceous vegetation on the site was established by determining the carbon stock value in the different plant formations in each village. The best carbon quantity was recorded in the village of Zamay while a low value was observed in Minawao. The amount of carbon was considered to be low in the vicinity of the refugee camp. The impact of the refugees on the carbon stock is therefore greater than that of the local population. The choice of an area for the creation of a refugee site should be crucial. Their settlement in the Sahelian savannah will lead to further desertification of the area, the effects of which are likely to be irreversible. Sustainable and participatory management is necessary in this locality in order to restore vegetation.

\section{Conflict of Interest}

The authors declare that they have no competing interest.

\section{Acknowledgements}

I could not finish this work without thanking the traditional administrative authorities and the local populations of Mayo Tsanaga.

\section{References}

[1] Saïdou, A., Dossa, A. F. E., Gnanglè, P. C., Balogoun, I., Aho, N., 2012. Evaluation du stock de carbone dans les systèmes agroforestiers à karité (Vitellaria paradoxa C. F. Gaertn.) et à néré (Parkia biglobosa Jacq. G. Don) en zone Soudanienne du Bénin. Bulletin de la Recherche Agronomique du Bénin (BRAB). 9 p. http://www.slire.net/document/1737.

[2] IPCC (Intergouvernemental Panel on Climat Change), 2003. Good Practice Guidance for land use, land-use change and forestry (LULUCF). Institute for Global Environmental Strategies, Hayama, Japon, 34p.

[3] Muoghalu, I. J., 2014. Vulnérabilité des systèmes biophysiques et socioéconomiques des savanes et formations boisées d'Afrique occidentale et centrale au changement climatique. African Forest Forum, 2 (14): 35 p. https://www.tandfonline.com/doi/full/10. 1080/10549811.2017.1296776af=R.

[4] Mbow, C., Verstraete, M. M., Sambou, B., Diaw, A. T., Neufeldt H., 2014. Allometric maize en zone Soudanienne du Bénin. Int. J. Biol. Chem. Sci., 6 (5): 2066-2082.

[5] Pascal, C., Peter, S., 2015. Climat: 30 questions pour comprendre la Conférence de Paris, Éditions Les Petits Matins. $200 \mathrm{p}$.

[6] Frédérick, D., 2015. Je suis Charlie Je suis Paris 2015, des antidotes au chaos du monde, Limours, les éditions Héliomir. 152 p. 
[7] Yameogo, G., Kiema, A., Yelemou, B., Ouedraogo, L., 2013. Caractéristiques des ressources fourragères herbacées des pâturages naturels du territoire de Vipalogo (Burkina Faso). Int. J. Biol. Chem. Sci., 7 (5): 2078-2091. DOI: http://dx.doi.org/10.4314/ijbcs.v7i5.25.

[8] Grouzis, M., 1987. Structure, productivité et dynamique des systèmes écologiques sahéliens (Mare d'Oursi, Burkina Faso). Thèse de Doctorat d'Etat, Université Paris Sud, Orsay, France. 338p.

[9] Djiteye, M. A., 1988. Composition, structure et production des communautés végétales sahéliennes: application à la zone de Niono (Mali). Thèse, Univ. Paris-sud Orsay, 150p.

[10] Wendsom, O. O., Alain, P. K. G., Saïdou, S., Daniel, I. et Aboubacar, T., 2019. Quantification de la Biomasse et stockage du carbone du massif forestier de l'Ecole Nationale des Eaux et Forêts de Dindéresso province du Houet au Burkina Faso. Int. J. Biol. Chem. Sci. 7: 3276-3288.

[11] Agonyissa, D., Sinsin, B., 1998. Productivité et capacité de charge des pâturages naturels au Bénin. Revue Élev. Méd. Vét. Pays Trop, 51: 239-246.

[12] Pagot, J., 1985. L'Elevage en Pays Tropicaux. Maisonneuve et Larose, ACCT. Paris.

[13] Ali A, Lebel, T., 2009. Recent trends in the Central and Western Sahel rainfall regime (1990-2007). Journal of Hydrology. 375: 52-64.

[14] Curasson, M., G., 1954. Etudes sur les pâturages tropicaux et subtropicaux. II. Les pâturages des principales régions. Rev. Elev. Méd. Vét. Pays Trop, 2: 103-120.

[15] Barth, R., 1970. Plantes Fourragères de la Zone Sahélienne d'Afrique. Afrika Studied Nr. 48: Weltforum Verlag, München, $298 \mathrm{p}$.

[16] Achard, F., Chanono, M., 1995. Un système d'élevage performant bien adapté à l'aridité à Toukounous, dans le Sahel nigérien. Sécheresse, 2: 215-222.

[17] Diatta, S., Douma, S., Chanono, M., Banoin, M., KaboréZoungrana, C. Y., Toudou, A., Akpo, L. E., 2004. Caractéristiques de Maerua crassifolia Forsk., ligneux fourrager des terres de parcours sahéliennes (Toukounous Filingué, Niger). Rev. Afr. Santé et Productions Animales, 2: 148-153.

[18] Douma, S., Diatta, S., Kabore-Zoungrana, C. Y., Banoin, M., Akpo, L. E., 2007. Caractérisation des terres de parcours sahéliennes: typologie du peuplement ligneux de la Station sahélienne Expérimentale de Toukounous au Niger. Journal des Sciences, 7: 1-16.

[19] Diatta, S., 2008. Modes de propagation d'un ligneux fourrager sahélien, Maerua crassifolia forsk. Thèse de doctorat en biologie végétale (3ème cycle), Option Ecologie, Université Check Anta Diop. Dakar. 103 p.

[20] Yoka, J., 2006. Contribution à l'étude phytoécologique des savanes de la zone d'Ollombo (Cuvette congolaise, République du Congo). Mémoire de Diplôme d'Etudes Approfondies, Faculté des Sciences, Université Marien Ngouabi, Brazzaville. 53p.

[21] Skerman, P. J., 1982. Les légumineuses fourragères tropicales. FAO, Rome. 535-543.
[22] Rabiou, H., Mahamane, M., Issaharou-Matchi, I., 2019. Impact de L'installation des Camps des Réfugiés, Retournés et Déplacés sur L'exploitation des Ressources Ligneuses dans la Région de Diffa. European Scientific Journal, Edition 2019, 15 (36): 1857- 7431.

[23] Isaac, N. T., Frédéric, R., Joseph, L. K. et Jean, D., 2017. Evaluation de la diversité floristique en herbacées dans le Parc National de Manda au Tchad. Int. J. Biol. Chem. Sci. 11 (4): 1484-1496, DOI: http://dx.doi.org/10.4314/ijbcs.v11i4.7.

[24] Wafo, T. G., 2008. Les aires protégées de l'Extrême-Nord Cameroun entre politiques de conservation et pratiques locales. Sciences de l'Homme et Société. Thèse de doctorat. Université d'Orleans (France), 335 p.

[25] Lindsey H., 2015. On the border and in the crossfire: Cameroon's war with Boko Haram, The Guardian, 12 (7): 123-150.

[26] UNHCR, 2018. Cameroun: Minawao-Profil du camp, Décembre, sur https://reliefweb.int(consulté le 15 mars 2019) -Reliefweb.

[27] UNHCR, 2020. Cameroun: Minawao-Profil du camp, Décembre, sur https://reliefweb.int(consulté le 14 juin 2020) - Reliefweb.

[28] Mbolo, M., 2005. Typologie et cartographie de la Végétation de la Reserve de la Biosphère de Dja. Thèse d'Etat ès Sciences Univ. Yaoundé I. 131 p.

[29] Ibrahima, A. et Abib F. C, 2008. Estimation du stock de carbone dans le facies arborés et arbustives des savanes Soudano-guinéennes de Ngaoundéré, Cameroun. Cameroon journal of experimental Biology; 1: 1-11.

[30] Mohamed B., Mohamed M., Jean-P. B., Laurent S.-A., Badr S., Mohamed H. \& Salwa E.-T., 2010. Estimation du stock de carbone organique dans la chênaie verte du Moyen Atlas marocain, Acta Botanica Gallica, 157: 3: 451-467.

[31] Valentini, S. G., 2007. Evaluation de la séquestration du carbone dans des plantations agroforestières et des jachères issues d'une agriculture migratoire dans les territoires autochtones de Talamanca, au Costa-Rica. Mémoire présenté pour l'obtention du Grade de Maître ès Sciences (M. Sc.), Option: Biologie Végétale. Faculté des Sciences de l'agriculture et de l'alimentation, Université Laval, Québec, Canada. $88 \mathrm{p}$.

[32] Yoka, J., Loumeto, J. J., Vouidibio, J., Epron D., 2013. Productivité herbacée des savanes de la Cuvette congolaise (Congo Brazzaville). Afrique SCIENCE. 1: 89-101.

[33] Dembele, F., 1996. Influence du feu et du pâturage sur la végétation et la biodiversité dans les jachères en zone soudanienne-nord du Mali. Cas des jeunes jachères du terroir de Missira (cercle de Kolokani). Thèse de doctorat, université de Droit, d'Economie et des Sciences, Aix Marseille III, 211p.

[34] Donfack, P., 1998. Végétation des jachères du NordCameroun: typologie, diversité, dynamique et production. Thèse d'Etat, Université de Yaoundé I, Cameroun, 270p.

[35] Tchobsala, 2011. Influence des coupes de bois sur la dynamique de la végétation naturelle de la zone périurbaine de Ngaoundéré (Adamaoua). Thèse de Docteur/PhD. Université de Yaoundé. 204p. 